\title{
THE ROLE OF MIDTRIMESTER AMNIOTIC FLUID LEPTIN AND ENDOTHELIN-1 LEVELS IN PREDICTION OF PREECLAMPSIA
}

\author{
Ahmet TAYYAR ${ }^{1}$, Ahter Tanay TAYYAR ${ }^{1}$, Ummuhan ABDULREZZAK ${ }^{2}$, Mustafa KULA², Mustafa TAS ${ }^{1}$, \\ Mehmet TAYYAR ${ }^{1}$ \\ ${ }^{1}$ Department of Gynecology and Obstetric, Erciyes University, Faculty of Medicine, Kayseri, Turkey \\ Department of Nuclear Medicine, Erciyes University, Faculty of Medicine, Kayseri, Turkey
}

\begin{abstract}
SUMMARY
Objective: We investigated leptin and endothelin-1 levels of amniotic fluid (AF) which was collected during genetic amniocentesis to use these parameters for prediction of preeclampsia.

Meterial and methods: The level of leptin and endothelin-1 were measured in the samples of AF which were obtained at 16-20 weeks of pregnancy during genetic amniocentesis. We recorded the patients who developed preeclampsia and who had healthy pregnancy and birth.

Results: AF leptin and endothelin-1 levels were significantly increased in the preeclamptic group compared to control group. Conclusion: As we detected increased level of AF leptin and endothelin-1 before preeclampsia symptoms develop we think that these proteins can be used to predict preeclampsia. Thus, early follow up and treatment of preeclampsia could decrease possible complications and related financial expense.
\end{abstract}

Key words: amniotic fluid, endothelin-1, leptin

Journal of Turkish Society of Obstetrics and Gynecology, (J Turk Soc Obstet Gynecol), 2012; Vol: 9 Issue: 1 Pages: 37 - 41

\section{MIDTRIMESTER AMNIYOTIK SIVI LEPTIN VE ENDOTELINN-1 DÜZEYLERININN PREEKLAMPSI GELIŞiMININ ÖNGÖRÜSÜNDEKİ ROLÜ}

\section{ÖZET}

Amaç: Genetik amniyosentez örneklerinde leptin ve endotelin-1 düzeylerini inceleyerek bunların preeklampsi gelişimini tahmin etmede kullanıp kullanılamayacă̆ını araştırmak.

Gereç ve yöntemler: Genetik amniyosentezle 16-20 haftalık gebelerden alınan amniyotik sivı (AS) örneklerinde leptin ve endotelin-1 düzeylerini araştırdık. Prospektif yapılan takiplerde preeklampsi gelişen ve sağlıklı doğum yapan hastaları kaydettik.

Bulgular: Preeklampsi gelişen grupta AS leptin ve endotelin-1 düzeyleri kontrol grubundan istatistiksel olarak yüksek bulunmuştur.

Yorum: AS'de henüz preeklampsi bulguları ortaya çıkmadan önce leptin ve endotelin-1'in yüksek düzeyde bulunması nedeniyle bu proteinlerin preeklampsiyi önceden tahmin etmede kullanılabileceğini düşünmekteyiz. Böylece preeklampsi takip ve tedavisinin erken başlatılması ile olası komplikasyonların ve bunlara bağlı oluşacak maddi giderlerin azaltılması mümkün olabilecektir.

Anahtar kelimeler: amniyotik sivl, endotelin-1, leptin

Türk Jinekoloji ve Obstetrik Derneği Dergisi, (J Turk Soc Obstet Gynecol), 2012; Cilt: 9 Sayl: 1 Sayfa: $37-41$

Address for Correspondence: Ahmet Tayyar. Millet cad. 41/510 Melikgazi, Kayseri Phone: (0532) 2221888

e-mail: drtayyar@yahoo.com

Received: 06 May 2011, revised: 28 August 2011, accepted: 20 September 2011, online publication: 08 . December 2011 


\section{INTRODUCTION}

Endothelial dysfunction triggered by antiangiogenic factors of placental origin is thought to play a role in the occurrence of preeclampsia(1). In recent years, it has been suggested that preeclampsia is not only an endothelial disease but also a generalized systemic inflammatory disease and is due to oxidative stress rather than hypoxia ${ }^{(2,3)}$.

Endothelin-1 is an amino acid which is released from endothelial cells including amnion cells and which has an endogen vasoconstrictor effect. It is involved in the regulation of vascular tone in hypertensive conditions. Increase in blood concentration of endothelin-1 has been reported to be associated with preeclampsia. Furthermore, it is presumed to play a key role in the relationship between primary placental disorder and ischemic endothelial dysfunction in preeclampsia(4).

Leptin is produced by peripheral adipocytes and also secreted from amnion cells in pregnancy. Human placenta contains high amount of leptin mRNA, and excess leptin secretion is thought to occur as a respond to hypoxia in patients with peeclampsia. Hypoxia has been shown to have caused increase in placental leptin gene expression, and furthermore, increase in placental leptin synthesis has been found to have related to preeclampsia. Moreover, leptin plays a role in T-cell activation $^{(5,6)}$.

A disturbance in uteroplacental perfusion and placentation is thought to be present before the onset of preeclampsia. Protein level alterations in amniotic fluid (AF) are presumed to reflect the early physiopathology of preeclampsia(1).

In this study, we aimed to examine endothelin-1 and leptin levels in genetic amniosynthesis samples to investigate if these contribute to estimation of preecplampsia that may develop in future.

\section{MATERIALS and METHODS}

The study was performed on patients who underwent genetic amniosynthesis between October 2009 and May 2010 in Obstetrics and Gynecology Department of Erciyes Medical School. Approval from Erciyes University Ethical and Audit Committee was obtained from the study. Finance was provided by Erciyes University Scientific Investigation Projects Unit.
Principles for human experiments set forth in Helsinki Declaration were followed, and consent was obtained from all study participants.

Genetic amniosynthesis was performed in patients who were found to have increased risk of detection of chromosome pathology by combined, triple test or quad test at 16-20. gestational weeks were administered. AF samples were taken to investigate leptin and endothelin-1 levels. AF samples were stored at -70 o until study was initiated.

Cases who developed diabetes mellitus, fetal loss, early membrane rupture and who were detected to have abnormal karyotype during the course of gestation were excluded from the study.

Pregnancy follow-ups and deliveries of patients were recorded prospectively. The group of patients who developed (11 subjects) preeclampsia and the control group without delivery complications (52 subjects) were formed. Diagnosis of preeclampsia was made upon blood pressure values measured as $140 \mathrm{~mm} \mathrm{Hg}$ and above systolic and $90 \mathrm{~mm} \mathrm{Hg}$ and above diastolic, edema and more than $300 \mathrm{mg}$, or 2+ with dipstick, of protein detection, which occurred after the $20^{\text {th }}$ gestational week.

Leptin level was measured through radioimmunoassay method using Leptin-Ria-CT (DIA source Immunoassay S.A., Belgium) kit, and endothelin-1 level was measured, again with radioimmunoassay method, using Endothelin-1 RIA (Phoenix Pharmaceuticals. Inc., ABD) kit.

For statistical investigations Student-t and MannWhitney U tests were used.

\section{RESULTS}

In our study, parameters such as maternal age, nulliparity, gestational week at which amniosynthesis was performed and proportion of female fetus were not differed between preeclampsia and control groups. While the delivery week was $34.6 \pm 2.8$ weeks in preeclampsia group, it was found as $38.5 \pm 2.1$ weeks in control group, indicating a statistically significant difference between them $(\mathrm{p}<0.05)$. As for the birth weights, it was found to be $2400 \pm 310 \mathrm{~g}$ and $3010 \pm$ $320 \mathrm{~g}$ in preeclampsia group and control group respectively, again indicating a statistically significant between-group difference $(\mathrm{p}<0.05)$ (Table I). 
Table I: Some characteristics of study groups.

\begin{tabular}{lccc}
\hline & $\begin{array}{c}\text { Preeclampsia } \\
\text { group } \\
\text { n: } \mathbf{~ 1 1}\end{array}$ & $\begin{array}{c}\text { Control } \\
\text { group } \\
\text { n: 52 }\end{array}$ & p \\
\hline Age (year) & $38.4 \pm 4.1$ & $35.1 \pm 3.4$ & $>0.05$ \\
Nulliparity (\%) & 11 & 14 & $>0.05$ \\
Gestational week at & & & \\
which amniosynthesis & & $18 \pm 1.0$ & $>0.05$ \\
was performed & $18.3 \pm 0.8$ & 48 & $>0.05$ \\
Female fetus (\%) & 54 & $38.5 \pm 2.1$ & $<0.05$ \\
Delivery week & $34.6 \pm 2.8$ & $3010 \pm 320$ & $<0.05$ \\
Birth weight (gr) & $2400 \pm 310$ & & \\
\hline
\end{tabular}

AF leptin level, which was found to be $16.2 \pm 2.1$ $\mathrm{ng} / \mathrm{ml}$ in preeclampsia group, was detected to be 8.4 $\pm 1.2 \mathrm{ng} / \mathrm{ml}$ in control group. AF leptin level was statistically significantly higher in preeclampsia group $(\mathrm{p}<0.05)$. AF endothelin-1 level was detected to be $34.1 \pm 2.1 \mathrm{pg} / \mathrm{ml}$ in preeclampsia group and $24.2 \pm 1.5$ $\mathrm{pg} / \mathrm{ml}$ in control group. Endothelin-1 level was detected to be statistically significantly higher in preeclampsia group $(\mathrm{p}<0.05)$ (Table II).

Table II: AF leptin and endothelin-1 levels in preeclampsia and control groups.

\begin{tabular}{lccc}
\hline & $\begin{array}{c}\text { Preeclampsia } \\
\text { group } \\
\mathbf{n}: \mathbf{1 1}\end{array}$ & $\begin{array}{c}\text { Control } \\
\text { group } \\
\text { n: } \mathbf{5 2}\end{array}$ & \\
\hline $\begin{array}{l}\text { Leptin } \\
(\mathrm{ng} / \mathrm{ml})\end{array}$ & $16.2 \pm 2.1$ & $8.4 \pm 1.2$ & $<0.05$ \\
$\begin{array}{l}\text { Endothelin-1 } \\
(\mathrm{pg} / \mathrm{ml})\end{array}$ & $34.1 \pm 2.1$ & $24.2 \pm 1.5$ & $<0.05$ \\
\hline
\end{tabular}

\section{DISCUSSION}

12 days after fertilization, AF starts to fill the gestational sac and this event takes place through active transport. Until mid-trimester, fetus is not the major source of AF. Fetal urine does not constitute the major part of AF until $20^{\text {th }}$ week. For these reasons, the major part of the AF samples taken during the period until $20^{\text {th }}$ week are placenta-originated $(7,8)$.

In preeclampsia there is a generalized endothelial dysfunction which is thought to be due to placentaoriginated antiangiogenic factor. Symptom starts to clear up after the placenta is separated. In preeclamptics AF levels of some proteins may differ in early period. It has been suggested that detection of this alteration may be used in early prediction of the disease ${ }^{(1,9-11)}$

In our study, the mean delivery week and mean birth weight of preeclamptic subjects was found as 34.6 and $2400 \mathrm{~g}$ respectively. In the study by Wang et al.(1), delivery week and fetal weight were found as 33.6 and $2040 \mathrm{~g}$ respectively, which are in line with our results. However, in the study by Margarit et al. ${ }^{(10)}$, gestational weeks and birth weight were found as 38 and $2864 \mathrm{~g}$ respectively, which figures we believe are relatively high for subjects with preeclampsia.

In our study, the mean age of the subjects was 38.4 and nulliparity ratio was $11 \%$. In the similar study by Wang et al.(1), in which they examined leptin and endothelin-1, the mean maternal age was 35 and nulliparity was $17 \%$. In the similar study by Chan et al.(11), in which they investigated leptin only, the mean maternal age was 35.3 and nulliparity was $25 \%$. Again in the similar study by Margarit et al. (10), in which they investigated endothelin-1 level only, the mean maternal age was 35 whereas nullyparity was not reported. The mean maternal age in our study is similar to those found in other studies. As for the parity, it has not a known effect on leptin and endothelin-1 levels subject to investigation.

In our investigation, gestational week at which aminosynthesis was performed in preeclamptic subjects was mean 18.8, whereas the proportion of female fetus was detected to be $54 \%$. In the study by Wang et al. (1), the mean gestational week was reported as 17.3, no fetal gender however was declared. In the study by Chan et al.(11), on the other hand, the mean gestational week was 18.3 and the proportion of female fetus was $50 \%$. In the investigation by Margarit et al. (10), amniosynthesis week was declared as 16-17, whereas no information about fetal gender was reported. Our results related to mean gestational week and fetal gender show similarity to those obtained in parallel studies in literature. In the investigation by Cagnacci et al.(12), AF leptin level was found to be higher in female fetuses. In our study, proportions of gender are very close to each other (Table I), which, therefore, we think have no effect on leptin levels.

In our study, we found that leptin levels were higher in preeclamptic subjects compared to control group (Table II). Chan et al. ${ }^{(11)}$ and Wang et al. ${ }^{(1)}$ obtained similar results in the studies they conducted. Inadequate endovascular invasion by cytotrophoblasts during early gestational period plays a role in the etiology of 
preeclampsia. This causes placental hypoxia which in turn leads to increase leptin secretion from trophoblasts ${ }^{(5)}$. On the other hand, leptin is secreted during acute inflammation. In some studies, it has been demonstrated that, like leptin, inflammatory cytokines such as tumor necrotizing factor (TNF) alpha and interleukin-6 has increased in preeclamptic patients. Inflammation is also though to play role in the physiopathology of $\operatorname{preeclampsia}^{(13)}$.

Elevation in AF leptin levels during mid-trimester in preeclamptic patients is the result of respond to inadequate invasion by cytotrophoblasts. Detection of this result before the clinical signs and symptoms of preeclampsia were emerged suggest that it can be used in early prediction of the disease ${ }^{(11)}$.

AF endothelin-1 level was found to be higher in preeclampsia group compared to control group (Table II). Similar results were obtained in the studies by Chan et al.11) and Margarit et al. ${ }^{(10)}$. This result indicates that endothelin-1 secretion in amniotic cavity increases before the onset of preeclampsia symptoms, and this peptide may be involved in the physiopathology of the disease. Endothelin-1 is known to regulate blood flow by constricting the placental veins. Furthermore, endothelin1 has been shown to activate inflammation modulating proteins such as nuclear factor $-\mathrm{kB}$ (NF-kB), c-Jun Nterminal kinase (JNKs). These results demonstrate that it may contribute to physiopathology of preeclampsia through inflammation ${ }^{(3,14)}$.

On the other hand, it is presumed that leptin and endothelin-1 affects vascular tone by exerting affect on endothelial nitric oxide, and hypertension thus develop ${ }^{(1)}$.

As a conclusion, in pregnant women, leptin and endothelin-1 levels may be determined by taking samples during amniosynthesis. If the levels of these proteins are detected to be high, preeclampsia should be considered to develop. Increase in frequency of antenatal follow-ups should be ensured. It has been reported in literature that medical treatments (such as aspirin, heparin) may be useful in selected cases $(15,16)$. Follow up with pre-estimation and early onset of treatment will reduce possible complications and financial costs they cause.

\section{REFERENCES}

1. Wang C N, Chang SD, Peng HH, Lee YS, Chang YL, et al. Change in amniotic fluid levels of multiple anti-angiogenic proteins before development of preeclampsia and intrauterine growth restriction. J Clin Endocrinol Metab 2010; 95: 1432141.

2. Hung TH, Burton GJ. Hypoxia and reoxygenation: a possible mechanism for placental oxidative stress in preeclampsia. Taiwan J Obstet Gynecol 2006; 45: 189- 200.

3. Redman CW, Sargent IL. Placental stres and pre-eclampsia: a revised view. Placenta 2009; 30 (suppl A): S38- S42.

4. Fiore G, Florio P, Micheli L, Nencini C, Rossi M, Cerratini D, et al. Endothelin-1triggers placental oxidative stres pathways: putative role in preeclampsia. J Clin Endocrinol Metab 2005; 90: 4205- 10.

5. Haugen F, Ranheim T, Harsem NK, Lips E, Staff AC, Drevon CA. Increased plasma levels of adipokines in preeclampsia: relationship to placenta and adipose tissue gene expression. Am J Physiol Endocrinol Metab 2006; 290: 326- 33.

6. Grosfeld A, Andre J, Huguel-De MS, Berra E, Pouyssegur J, Guerre-Millo M. Hypoxia-inducible factor1 transactivates the human leptin gene promoter. J Biol Chem 2002; 277: 429537.

7. Madena AB, Fieni S. Amniotic fluid dynamics Acta Biomed 2004; 75 (suppl): $11-3$.

8. Touboul C, Boulvain M, Picone O, Levaillant JM, Frydman R, Senat M . Normal fetal urine production rate estimated with 3-dimensional ultrasonography using the rotational technique (virtual organ computer-aided analysis). Am J Obstet Gynecol 2008; 199: 51- 5.

9. Iurio DR, Marinomi E, Anceschi MM, Eamiliani S, Letizia G, Cosmi EV. Amniotic fluid endothelin-1 levels are increased in pregnancy-inuced hypertension and intrauterino growth retardation. Am J Reprod Imunol 1996; 36: 260- 3.

10. Margarit L, Griffiths A, TsapanosV, Decavalas G, Gumenos D. Second trimester amniotic fluid endothelin concentration. A possible predictor for pre-eclampsia. J Obstet Gynaecol 2005; 25: 18- 20 .

11. Chan TF, Su JH, Chung YF, Hsu YH, Yeh YT, Yuan SS. Elevated amniotic fluid leptin levels in prenant women who are destined to develop preeclampsia. Acta Obstet Gynecol Scand 2006; 85: 171- 4 .

12. Cagnacci A, Arangino S, Caretto S, Mazza V. Volpe A. Sexual dimorphism in the levels of amniotic fluid leptin in pregnancies at 16 weeks of gestation relation to fetal growth. Eur J Obstet Gynecol Reprod Biol; 2006; 124: 53- 7.

13. Bartha IL, Romero-Carmona R, Escobar-Llompart M, Comino. 
Delgado R. The relationship between leptin and inflammatory cytokines in women with pre-eclampsia. BJOG 108: 1272- 6

14. Fried G, Sand A, Ostlund E, Andersson E, Bystrom B, Stabi B. Endothelin-1 and macrophage colony-stimulating factor are co-localized in human amnion membrane cells and secreted into amniotic fluid. Life Sci Med 2003; 9: 719- 24.

15. Sergis F, Clara DM, Galbriella F. Prophylaxis of recurrent preeclampsia: Low molecular weight heparin plus low-dose aspirin versus low-dose aspirin alone. Hypertension Pregnancy 2006; 25: 115 .

16. Sibai BM, Cunningham FG. Prevention of preeclampsia and eclampsia. In: Lindheimer MD, Roberts JM, Cunningham FG eds. Chesley's Hypertensive Disorders of Pregnancy, 3rd ed. New York, Elsevier, 2009: 215. 